\author{
Stanistaw Prutis ${ }^{1}$
}

\title{
Zróżnicowanie własnościowe gospodarstw rolnych - synchronizacja pojęć
}

1. Przekształcenia własnościowe w rolnictwie polskim lat dziewięćdziesiątych $\mathrm{XX}$ w. charakteryzowały się tym, iż w znacznie mniejszym stopniu przedmiotem przekształceń były stosunki społeczno-gospodarcze władania gruntami rolnymi (baza ekonomiczna ustroju gospodarczego), natomiast istotne zmiany wprowadzono w sferze nadbudowy - w miejsce stosowanych w państwach socjalistycznych typów i form własności nastąpił powrót do tradycyjnego rozróżnienia własności prywatnej oraz własności publicznej.

W poprzednim, jak się żartobliwie określa - „słusznie minionym” ustroju gospodarczym układ stosunków własnościowych był schematycznie prosty. W zakresie własności rzeczy mających charakter środków produkcji funkcjonowały dwa typy własności: własność społeczna oraz własność indywidualna. W ramach typu własności społecznej wyróżniono trzy formy własności: ogólnonarodową czyli państwową, własność spółdzielczą oraz własność innych organizacji społecznych. Natomiast własność indywidualna przybierać mogła formę własności drobnotowarowej bądź kapitalistycznej. Osobną formę własności stanowiła własność osobista, której przedmiotem były środki konsumpcji, a nie środki produkcji. Schemat ten miał podstawy merytoryczne w Konstytucji PRL z 1952 r., a był expressis verbis regulowany przepisami art. 126-131 Kodeksu cywilnego z 1964 r. Schemat ten znajdował pełne zastosowanie w odniesieniu do własności rolniczej, która jest przecież własnością środków produkcji. Dlatego też podstawowa kategoryzacja gospodarstw rolnych, oparta o kryterium własnościowe wyodrębniała: gospodarstwa państwowe (działające w formie organizacyjno-prawnej państwowych przedsiębiorstw gospodarki rolnej lub państwowych gospodarstw rolnych), gospodarstwa spółdzielcze (rolnicze spółdzielnie produkcyjne) oraz gospodarstwa indywidualne (,stanowiące prywatną własność ich posiadaczy"2).

Uniwersytet w Białymstoku.

Sformułowanie użyte w art. 1 ust. 1 zdanie 2 dekretu PKWN z dnia 6 września 1944 r. o przeprowadzeniu reformy rolnej (tekst jednolity Dz.U. z 1945 r. Nr 3, poz.13). 
Dodać należy, że podmiotowe zróżnicowanie własności rolniczej pociągało za sobą zróżnicowanie jej ochrony. Ochrona własności społecznej była wyraźnie uprzywilejowana i najdalej idąca. ${ }^{3} \mathrm{~W}$ sektorze rolnictwa stosowana była sztandarowa zasada polityki rolnej - zasada preferencji gospodarstw uspołecznionych, a celem polityki rolnej były socjalistyczne przekształcenia rolnictwa indywidualnego. Przełom polityczny przyniosło zawarcie Porozumienia Rzeszowsko-Ustrzyckiego, ${ }^{4}$ znajdujące swój wyraz prawny w nowelizacji art. $131 \mathrm{kc} .{ }^{5}$ a następnie w noweli konstytucyjnej z 1983 r., ${ }^{6}$ która wprowadziła nowy przepis tej treści, że „PRL (...) otacza opieką indywidualne rodzinne gospodarstwa rolne pracujących chłopów, gwarantuje trwałość tych gospodarstw, udziela im pomocy", z tym że utrzymano formułę: „rozszerza powiązania indywidualnych gospodarstw rolnych z socjalistyczną gospodarką narodową". Ten stan prawny przetrwał do roku 1990.

2. Diametralne zmiany w ustroju gospodarczym zapoczątkowało uchwalenie przez Sejm w dniu 29 grudnia 1989 r. noweli konstytucyjnej, ${ }^{7}$ w której uchylono przepisy o socjalistycznym systemie gospodarczym oraz planowym charakterze gospodarki, wprowadzając gospodarkę rynkową, opartą na swobodzie działalności gospodarczej przez wszystkie podmioty, bez wyróżniania jakiejkolwiek uprzywilejowanej kategorii. ${ }^{8}$ Uchylono również wszystkie przepisy dające wyraz zróżnicowaniu własności według kryterium podmiotowego i zróżnicowanej ochronie tak pojmowanej własności. Przepisy Kodeksu cywilnego definiujące typy i formy własności utraciły moc 1 października 1990 r. ${ }^{9}$

Przełom, jaki dokonał się w latach 1989/90 musiał zaważyć na kształcie prawa i jego fundamentalnych konstrukcjach. W sferze prawa własności zaproponowano podstawowy podział na własność prywatną i własność publiczną, będący podziałem pochodnym od zasadniczego podziału prawa na prawo prywatne i prawo publiczne. ${ }^{10}$ Dyskusje toczone na temat współczesnej stratyfikacji własności w Polsce na swój sposób zamykają rozstrzygnięcia podjęte w Konstytucji Rzeczypospolitej Polskiej z 1997 r. ${ }^{11}$ O modelowym charakterze własności prywatnej decyduje art. 20 Konstytucji RP, który stanowi, że: „Społeczna gospodarka rynkowa oparta na wolności działalności gospodarczej, własności prywatnej oraz solidarności, dialogu i współpracy partnerów społecznych stanowi podstawę ustroju gospodarcze-

Punktem wyjścia był tu art. 129 kc., który stanowił, że „przy tłumaczeniu i stosowaniu przepisów (...) Kodeksu należy mieć na względzie, że własność społeczna, jako podstawa ustroju PRL, pozostaje pod szczególną ochroną prawa”.

Porozumienie zawarte pomiędzy Komitetem Strajkowym Rolników a Rządem PRL dnia 18 lutego $1981 \mathrm{r}$.

Zmiana Kodeksu cywilnego z dnia 26 marca 1982 r. (Dz.U. Nr 11, poz. 81 ze zm.).

Dz.U. Nr 39, poz. 175.

Dz.U. Nr 75, poz. 444.

Na ten temat por. System Prawa Prywatnego tom 3 - Prawo rzeczowe, E. Gniewek (red.), Wydanie 3, Warszawa 2013 , s. 262 i n.

Na mocy ustawy z dnia 28 lipca 1990 r. o zmianie ustawy - Kodeks cywilny, Dz.U. z 1990 r. Nr 55, poz. 321.

Por. System Prawa Prywatnego, tom 3, op. cit., s.294.

Ustawa z dnia 2 kwietnia 1997 r. (Dz.U. Nr 78, poz. 483), weszła w życie 17 października 1997 r. 
go Rzeczypospolitej Polskiej”. Konstytucja potwierdza, iż Rzeczpospolita Polska chroni własność i prawo dziedziczenia (art. 21 ust. 1) i, co ważne, sama Konstytucja przewiduje równą dla wszystkich ochronę prawną praw majątkowych, w tym przede wszystkim własności (art. 64 ust. 2 Konstytucji RP).

Równa dla wszystkich ochrona prawna praw majątkowych, w tym prawa własności, nie eliminuje potrzeby i możliwości co do zaliczania określonych podmiotów i ich mienia do kategorii własności prywatnej lub publicznej, albowiem zróżnicowane są prawne reguły wykonywania tych kategorii własności. Autorzy systemu prawa prywatnego słusznie stwierdzają, że: „O ile do własności prywatnej można i należy stosować w pełni cywilistyczną zasadę, że to, co nie jest zakazane - jest dozwolone, to do własności publicznej stosuje się zasadę prawnoadministracyjną, że dozwolone jest to, co jest prawem określone. Prowadzi to do kazuistycznej regulacji prawnej w zakresie zarówno zarządzania, jak i rozporządzania własnością publiczną" ${ }^{12}$ Autorzy Ci zwracają uwagę, iż istnieją różne sytuacje prawne, które są trudne do zakwalifikowania (np. zabytki należące do zasobu dziedzictwa kulturowego). Proponują swoistą regułę interpretacyjną, że w razie wątpliwości należy się opowiedzieć za przynależnością danego mienia do kategorii własności prywatnej z uwagi na uznanie własności prywatnej jako podstawowej w systemie gospodarki wolnorynkowej. ${ }^{13}$

Z uwag natury ogólnej dotyczącej kategoryzacji własności w ogólności dodać należy, iż zasadniczym kryterium wyodrębnienia własności publicznej jest jej cel, jakim jest użytek publiczny, zakładający dobro ogółu. Znawcy problemu proponują uznać, że własność publiczna występuje w dwóch formach:

1) w ścisłym tego słowa znaczeniu (sensu stricto) oraz

2) w szerszym tego słowa znaczeniu (sensu largo).

Własność publiczna w pierwszym znaczeniu przynależy tylko tym podmiotom, które dysponują kompetencjami władczymi. Natomiast własność publiczna w szerszym znaczeniu przynależy wszelkim podmiotom, które realizują cele o charakterze publicznym. ${ }^{14}$ Przyznać wszakże należy, że dla niektórych jednostek organizacyjnych cele o charakterze publicznym mają charakter podstawowy, a dla innych tylko uboczny.

3. Odnosząc ogólną charakterystykę przemian własnościowych do rolnictwa, jako działu gospodarki narodowej, poczynić można następujące konstatacje: 
1) własność rolnicza pozostaje nadal wyodrębnionym funkcjonalnie rodzajem własności, ze względu na przedmiot, jakim jest gospodarstwo rolne; ${ }^{15}$

2) zachowane zostało podmiotowe zróżnicowanie gospodarstw rolnych (gospodarstwa państwowe, gospodarstwa spółdzielcze, gospodarstwa rolników indywidualnych);

3) nie budzi wątpliwości zaliczenie własności spółdzielczej (gospodarstw spółdzielczych) i własności rolników indywidualnych do kategorii własności prywatnej, albowiem celem tych gospodarstw jest działanie w interesie własnym, czyli prywatnym;

4) wątpliwości budzi status prawny mienia stanowiącego własność Skarbu Państwa (własność państwową), w sytuacji kiedy wykorzystanie uprawnień własnościowych powierzono Agencji Nieruchomości Rolnych, czy tę formę własności państwowej zaliczyć należy do kategorii własności publicznej, czy też prywatnej (?);

5) istotnym faktem prawnym jest ustanowiona przepisem art. 23 Konstytucji RP z 1997 r. zasada, że podstawą ustroju rolnego państwa jest gospodarstwo rodzinne.

4. Gdy chodzi o państwową własność rolniczą odnotować należy przede wszystkim istotną zmianę organizacyjną. Nieruchomości rolne, będące przedmiotem własności państwowej, funkcjonujące do 1992 roku w formie państwowych przedsiębiorstw gospodarki rolnej, bądź administrowane przez terenowe organy administracji państwowej w ramach Państwowego Funduszu Ziemi, zostały skoncentrowane organizacyjnie w Zasobie Własności Rolnej Skarbu Państwa. Zasób ten pozostaje w dyspozycji Agencji Nieruchomości Rolnych. Agencja to wyspecjalizowana struktura organizacyjna, utworzona przepisami ustawy o gospodarowaniu nieruchomościami rolnymi Skarbu Państwa. ${ }^{16}$ Agencja jest państwową osobą prawną prawa publicznego i prawa prywatnego, łączącą w sobie funkcje centralnego organu administracji z zadaniami podmiotu gospodarczego, odpowiedzialnego za gospodarowanie państwowym mieniem rolniczym w skali całego kraju. ${ }^{17} \mathrm{~W}$ zakresie gospodarowania państwowym mieniem rolnym Agencja jest instytucją powierniczą wykonującą we własnym imieniu, lecz na rzecz Skarbu Państwa, prawa i obowiązki wynikające z prawa własności i innych praw rzeczowych przysługujących w stosunku do państwowego mienia rolnego.

15 Własność rolnicza jest związana z gospodarstwem rolnym, ponieważ charakterystyczne funkcje własności rolniczej ujawniają się wtedy, gdy występuje ona jako czynna masa majątkowa.

16 Ustawa z dnia 19 października 1991 r. (tekst pierwotny: Dz.U. Nr 107, poz. 464; tekst jednolity Dz.U. 2012 , poz. 1187).

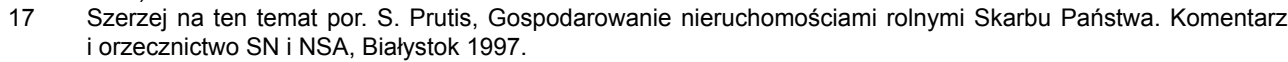


Zgodnie z art. 6 ww. ustawy, Agencja realizuje zadania „wynikające z polityki państwa", w szczególności w zakresie: 1) tworzenia oraz poprawy struktury obszarowej gospodarstw rodzinnych; 2) tworzenia warunków sprzyjających racjonalnemu wykorzystaniu potencjału produkcyjnego Zasobu Własności Rolnej Skarbu Państwa; 3) restrukturyzacji oraz prywatyzacji mienia Skarbu Państwa użytkownego na cele rolnicze; 4) obrotu nieruchomościami rolnymi i innymi składnikami majątku Skarbu Państwa użytkowanymi na cele rolne; 5) administrowania zasobami majątkowymi Skarbu Państwa przeznaczonymi na cele rolne. Nadto Agencja realizuje również zadania określone odrębnymi przepisami, a w szczególności przepisami o kształtowaniu ustroju rolnego ${ }^{18}$ (art. 6 ust. 2 ww. ustawy).

Nie sposób oczywiście podporządkowywać poszczególnych składników majątkowych do realizacji konkretnych zadań Agencji. Można wszakże rozgraniczyć zadania Agencji, służące realizacji polityki rolnej w zakresie kształtowania ustroju rolnego naszego państwa, w szczególności w drodze restrukturyzacji oraz prywatyzacji mienia Skarbu Państwa, od zadań natury gospodarczej polegających na prowadzeniu gospodarstwa rolnego w oparciu o składniki majątkowe, będące własnością państwową, a tworzące wyodrębnioną, zorganizowaną całość gospodarczą.

Realizacja celów polityki rolnej w zakresie kształtowania ustroju rolnego nie jest prowadzona w interesie samej Agencji, a służy użyteczności publicznej, czyli prowadzona jest w interesie ogółu. Dlatego też składniki majątkowe państwowej własności rolniczej zaangażowane w realizację takich celów ogólnych, odpowiadają kryterium własności publicznej sensu largo. Natomiast prowadzenie gospodarstwa rolnego jest komercyjną działalnością gospodarczą prowadzoną w interesie właściciela gospodarstwa (produkcja na samozaopatrzenie lub towarowa produkcja żywności). Dotyczy to również gospodarstw rolnych, prowadzonych przy wykorzystaniu państwowej własności rolniczej (gospodarstwo rolne prowadzone przez spółkę Agencji, gospodarstwo prowadzone na podstawie umowy $\mathrm{z}$ administratorem, czy gospodarstwo prowadzone na gruntach rolnych dzierżawionych od Agencji). Dlatego też, pomimo uznawania Agencji Nieruchomości Rolnych za osobę prawa publicznego, ,,wyrażającą interes publiczny”, ${ }^{19}$ nie można uznać, iż cały majątek Skarbu Państwa powierzony Agencji stanowi własność publiczną. Majątek produkcyjny, zorganizowany w wyodrębnioną całość gospodarczą w postaci gospodarstwa rolnego, należy traktować jako należący do kategorii własności prywatnej.

Za prezentowanym stanowiskiem przemawia również argument, który można wydedukować z przepisów wywłaszczeniowych. Zgodnie z art. 21 ust. 2 Konstytucji RP, wywłaszczenie jest dopuszczalne jedynie wówczas, gdy jest dokonywane na cele publiczne i za słusznym odszkodowaniem. W ustawodawstwie zwykłym, 
gdzie określono cele publiczne, na które może nastąpić wywłaszczenie (art. 6 ustawy o gospodarowaniu nieruchomościami ${ }^{20}$ ) nie zostało uwzględnione prowadzenie produkcji rolniczej. Co więcej, we wcześniejszych regulacjach ustawowych podkreślono wyraźnie, iż wywłaszczenie nie może nastąpić na cele produkcji rolniczej. ${ }^{21}$

Dotychczasowe rozważania doprowadzają do konstatacji, że gospodarstwo rolne jako zespół czynników produkcji rolnej, stanowiący zorganizowaną całość gospodarczą, nie służy realizacji celu, czy interesu publicznego, a zatem w klasyfikacji własności na kategorie własności publicznej oraz prywatnej, gospodarstwo rolne zaliczać należy do kategorii własności prywatnej, niezależnie od charakteru prawnego (osoba prawna, czy osoba fizyczna) podmiotu będącego właścicielem gospodarstwa.

5. Konstatacja powyższa odnosi się również do gospodarstw spółdzielczych prowadzonych przez spółdzielnie produkcji rolnej, głównie przez rolnicze spółdzielnie produkcyjne. Zgodnie z art. 138 prawa spółdzielczego przedmiotem działalności rolniczej spółdzielni produkcyjnej (r.s.p.) jest prowadzenie wspólnego gospodarstwa rolnego oraz działalności na rzecz indywidualnych gospodarstw rolnych członków spółdzielni. ${ }^{22}$ Wspólne gospodarstwo rolne r.s.p. stanowi własność spółdzielczą. Jak więc rozumieć przepis art. 3 prawa spółdzielczego, wprowadzony nowelizacją z dnia 7 lipca 1994 r., ${ }^{23}$ stanowiący, że majątek spółdzielni jest prywatną własnością jej członków. Przepis ten budził wątpliwości tej natury, czy właścicielem majątku spółdzielni - podmiotem prawa własności jest spółdzielnia jako osoba prawna, czy jest to rodzaj współwłasności przysługującej członkom spółdzielni jako osobom fizycznym. Sąd Najwyższy orzekając zarówno w sprawach cywilnych, jak i karnych zajmował stanowisko jednoznaczne, że art. 3 prawa spółdzielczego nie statuuje bynajmniej zasady, iż członkowie spółdzielni są współwłaścicielami nieruchomości spółdzielczych, czy innych praw, a zawiera jedynie określenie majątku spółdzielczego, traktowanego dawniej jako mienie społeczne, i to tylko z ekonomicznego punktu widzenia. ${ }^{24}$ Przepis art. 3 nie pozbawia spółdzielni własności jej majątku, a jedynie zalicza własność należącą do spółdzielni, jako osoby prawnej, do kategorii własności prywatnej, a nie jak ongiś, spółdzielczej. Własność taka, w rozumieniu prawa karnego, pozostaje jednak własnością cudzą, a jej przedmiot jest cudzym mieniem także dla członka tej spółdzielni. ${ }^{25}$ Wywody uzasadnień są w zasadzie trafne; nie można jedynie podzielić poglądu, jakoby zanikła kategoria własności spółdzielczej. Własność spółdzielcza jest, tak jak poprzednio, kategorią wła-

Ustawa z dnia 21 sierpnia 1997 r. (tekst jednolity Dz.U. z 2014 r., poz. 518).

Por. art. 50 ust. 2 ustawy z dnia 29 kwietnia 1985 r. o gospodarce gruntami i wywłaszczaniu nieruchomości (tekst jednolity Dz.U. z 1989 r., poz. 1474).

Ustawa z dnia 16 września 1982 r. (tekst jednolity Dz.U. z 2013 r., poz. 1443).

Dz.U. Nr 90, poz. 419; zmiana weszła w życie 26 września 1994 r.

Por. uchwała Sądu Najwyższego z dnia 6 lutego 1996 r. (III CZP 4/96, OSNC 1996, nr 4, poz. 58).

Por. wyrok Sądu Najwyższego z dnia 9 lipca 2003 r. (III KK 334/02, Lex nr 80298). 
sności wyodrębnioną w oparciu o kryterium podmiotowe. Zmiana polega na tym, iż ongiś własność spółdzielcza zaliczana była do własności społecznej, a obecnie trafnie zaliczana jest do własności prywatnej, albowiem służy realizacji interesów spółdzielni i jej członków, a nie realizacji celu publicznego. Nie ulega zatem wątpliwości fakt wyodrębnienia kategorii własności spółdzielczej w oparciu o kryterium podmiotowe, albowiem inne są reguły wykonywania własności państwowej, spółdzielczej jako własności korporacji i własności indywidualnej. Własność spółdzielcza, w odróżnieniu od własności państwowej, która może służyć celom publicznym lub prywatnym, zaliczana może być wyłącznie do kategorii własności prywatnej, co potwierdza trafność zapisu art. 3 prawa spółdzielczego. W konsekwencji wspólne, spółdzielcze gospodarstwo rolne należy zaliczyć do kategorii gospodarstw prywatnych.

6. Rezygnacja ze stosowanych w układzie socjalistycznej gospodarki planowej, przeciwstawnych sobie, kategorii własności spółdzielczej oraz własności indywidualnej spowodowała, że gospodarstwa rolne będące własnością rolników indywidualnych „stały się" przedmiotem własności prywatnej. O ile ustawodawstwo i doktryna zrezygnowały z operowania kategorią ,,własności indywidualnej”, gdy chodzi o prezentację nowej rzeczywistości gospodarczej, to wątpliwości budzi na ile aktualne i adekwatne jest operowanie kategorią ,gospodarstwa indywidualnego”. Zachowana została konstrukcja (pojęcie) prawna ,rolnika indywidualnego”. A skoro tak, wydawałoby się, iż ,rolnik indywidualny” to właściciel (posiadacz samoistny) ,gospodarstwa indywidualnego", to gospodarstwo prowadzone przez takiego rolnika jest gospodarstwem indywidualnym. Taka prosta i logiczna relacja nie znajduje potwierdzenia w obowiązującym ustawodawstwie. Stało się tak na skutek ustawowej regulacji pojęcia ,gospodarstwo rodzinne”.

O tym, że ,gospodarstwo rodzinne” jest podstawą ustroju rolnego naszego państwa przesądził art. 23 Konstytucji RP. Uznanie gospodarstwa rodzinnego za ,podstawę" ustroju oznacza, że jest ono zasadniczym elementem tego ustroju. Regulacja konstytucyjna co do pozycji ,gospodarstwa rodzinnego" odpowiada faktycznemu stanowi rzeczy, jaki ukształtował się w rozwoju historycznym naszego rolnictwa. Norma konstytucyjna daje wyraz przekonaniu, iż ten stan rzeczy ma być utrzymany także w przyszłości. Podkreśla się, że jest to konstytucyjna zasada programowa, która pozostaje wytyczną polityczną na przyszłość. ${ }^{26}$

Pierwsza, ustawowa regulacja konstrukcji prawnej „gospodarstwa rodzinnego" podjęta została w ustawie z dnia 11 kwietnia 2003 r. o kształtowaniu ustroju rolnego. Cel ustawy określony jest w jej tytule, a przedmiotem regulacji są zasady kształtowania ustroju rolnego państwa przez: 
1) poprawę struktury obszarowej gospodarstw rolnych,

2) przeciwdziałanie nadmiernej koncentracji nieruchomości rolnych,

3) zapewnienie prowadzenia działalności rolniczej w gospodarstwach rolnych przez osoby o odpowiednich kwalifikacjach.

W celu realizacji mechanizmów przewidzianych w ustawie ustawodawca wprowadził pojęcie gospodarstwa rodzinnego. Zgodnie z art. 5 ust. 1 ustawy, za gospodarstwo rodzinne uważa się gospodarstwo rolne:

1) prowadzone przez rolnika indywidualnego oraz

2) w którym łączna powierzchnia użytków rolnych nie jest większa niż 300 ha. Natomiast za rolnika indywidualnego, o którym mowa w definicji gospodarstwa rodzinnego, uważa się osobę fizyczną będącą właścicielem, użytkownikiem wieczystym, samoistnym posiadaczem lub dzierżawcą nieruchomości rolnych, których łączna powierzchnia użytków rolnych nie przekracza 300 ha, posiadającą kwalifikacje rolnicze oraz co najmniej od 5 lat zamieszkałą w gminie, na obszarze której jest położona jedna z nieruchomości rolnych wchodzących w skład gospodarstwa rolnego i prowadząca przez ten okres osobiście to gospodarstwo (art. 6 ust. 1 ustawy).

Powyższa definicja gospodarstwa rodzinnego spotkała się ze zdecydowaną, krytyczną oceną doktryny, ${ }^{27}$ która dokonała szczegółowej analizy i oceny poszczególnych przesłanek użytych w konstrukcji wyżej przytoczonej definicji ustawowej. W tym miejscu podnieść należy zastrzeżenie natury generalnej. Chodzi o to, że ustawa jedynie nominalnie operuje pojęciem „gospodarstwa rodzinnego”, ponieważ sformułowana przez ustawodawcę definicja nie zawiera żadnych odniesień do „rodzinnego" charakteru gospodarstwa. Gospodarstwo rodzinne jest to gospodarstwo, w którym mamy ścisły związek produkcji rolnej ze wspólnotą domową, w którym działalność gospodarcza jest sprzężona $\mathrm{z}$ rodziną. ${ }^{28} \mathrm{~W}$ doktrynie funkcjonuje określenie, że na gospodarstwo rodzinne składa się gospodarstwo rolne, gospodarstwo domowe oraz rodzina tam funkcjonująca. Gospodarstwo rodzinne to miejsce życia i pracy rodziny rolniczej. Rozmiar takiego gospodarstwa powinien rodzinie „w nim i z niego" żyjącej zapewnić odpowiedni standard życiowy. Gospodarstwo rodzinne jako warsztat wspólnej pracy winno zapewnić pracę członkom rodziny, a dochody

27 Por. w szczególności A. Lichorowicz, Regulacja obrotu gruntami rolnymi według ustawy z dnia 11 kwietnia 2003 r. o kształtowaniu ustroju rolnego na tle ustawodawstwa agrarnego Europy Zachodniej, „Studia luridica Agraria" 2005, t. IV, s. 9-30; A. Majewski, Problematyka prawna kwalifikacji do prowadzenia działalności rolniczej w gospodarstwach rolnych, „Studia luridica Agraria” 2005, t. IV, s. 125-142; S. Prutis, Kształtowanie ustroju rolnego - potrzeba nowej regulacji ustawowej, „Studia luridica Agraria” 2005, t. V, s. 168-184. 
z gospodarstwa, będące wynikiem pracy, zapewniać poziom egzystencji, mierzony parytetem dochodów w rolnictwie i poza rolnictwem. ${ }^{29}$

Definicja ,gospodarstwa rodzinnego" uregulowana przepisami omawianej ustawy nie zawiera jakichkolwiek odniesień do tak rozumianego rodzinnego charakteru gospodarstwa. Odniesień takich brak także w elementach konstrukcyjnych definiujących gospodarstwo rodzinne. Wszelkie przesłanki podmiotowe (kwalifikacje rolnicze, zameldowanie, a szczególnie osobiste prowadzenie gospodarstwa rozumiane jako podejmowanie wszelkich decyzji) dotyczą „,rolnika indywidualnego”, a więc pojedynczej osoby fizycznej prowadzącej gospodarstwo. Bazując na pojęciu ,rolnika indywidualnego" jako prowadzącego gospodarstwo, który spełnia wymagania, czy kryteria postawione mu wyłącznie osobiście (pojedynczo), poprzez proste dodanie kryterium ,,powierzchni użytków rolnych nie większej niż 300 ha” ustawodawca tworzy pojęcie „gospodarstwa rodzinnego" (art. 5 ust. 1 ustawy). Wydaje się więc, że ustawodawca skorzystał z określenia ,gospodarstwo rodzinne”, wyodrębnionego w oparciu o kryterium obszarowe (300 ha), do podziału ogółu gospodarstw rolnych będących prywatną własnością rolników, na gospodarstwa rodzinne i nie będące gospodarstwami rodzinnymi. Ustawodawca w przyjętych rozwiązaniach prawnych nie jest konsekwentny, zachowując pojęcie „,rolnik indywidualny”, zaprzestał używania pojęcia ,gospodarstwo indywidualne”. Gospodarstwo prowadzone przez rolnika o powierzchni do 300 ha to - według ustawodawcy - gospodarstwo rodzinne. Gospodarstwo o powierzchni przekraczającej 300 ha nie ma prawnie określonej nazwy. Użycie określenia ,gospodarstwo indywidualne” byłoby nielogiczne, ponieważ prowadzący takie gospodarstwo nie jest rolnikiem indywidualnym, albowiem w ustawowej definicji ,rolnika indywidualnego" również obowiązuje norma obszarowa 300 ha. Trudno mówić o gospodarstwie indywidualnym prowadzonym przez rolnika nie będącego rolnikiem indywidualnym. Użycie określenia ,gospodarstwo prywatne" również nie załatwia sprawy, albowiem, co wykazano, wszystkie kategorie gospodarstw rolnych nie służą realizacji celów publicznych, a zatem winny być zakwalifikowane do własności prywatnej. Terminologia dotycząca prywatnych gospodarstw rolnych wymaga niewątpliwie uporządkowania.

Zdaniem moim, skoro ustawodawca określił pojęcie „,rolnika indywidualnego” i, na bazie tego pojęcia (dodając jedynie kryterium obszarowe), skonstruował kategorię gospodarstwa rolnego prowadzonego przez tego rolnika, to - logicznie rzecz biorąc - powinien je nazwać ,gospodarstwem indywidualnym”. Nazwa ,gospodarstwo indywidualne" jest adekwatna do treści ustawy, która wszelkie wymagania, czy kwalifikacje natury podmiotowej stawia rolnikowi jako osobie fizycznej prowanictwa rodzinnego w Polsce i innych państwach Unii Europejskiej, 23-24 października 2014 r., Warszawa, Szkoła Główna Gospodarstwa Wiejskiego. Materiały konferencji w druku. 
dzącej gospodarstwo rolne. Procedura realizacji celów ustawy w zakresie kształtowania ustroju rolnego byłaby taka sama, gdyby ustawodawca użył zbiorczego określenia „gospodarstwa indywidualnego”, w ramach którego dopiero wyodrębniłby kategorię „gospodarstwa rodzinnego", chociażby przy użyciu kryterium obszarowego, choć poprawne byłoby nawiązanie do merytorycznych kryteriów „rodzinnego" charakteru gospodarstw. W ten sposób pojęcie „gospodarstwa indywidualnego" oznaczałoby gospodarstwo prowadzone przez rolnika - osobę fizyczną.

Pojęcie „gospodarstwo indywidualne” obejmować powinno wszystkie gospodarstwa prowadzone przez rolników - osoby fizyczne, niezależnie od ich wielkości. Możliwe jest oczywiście zróżnicowanie gospodarstw indywidualnych na gospodarstwa rodzinne, czy wielkoobszarowe (farmerskie), także przy wykorzystaniu kryterium obszarowego. Do gospodarstw indywidualnych zaliczyć należy także gospodarstwa prowadzone przez spółki rolników, nie posiadające osobowości prawnej. Natomiast, gdy chodzi o gospodarstwa prowadzone przez grupy producentów rolnych, będące przedsiębiorcami mającymi osobowość prawną, gospodarstwa rolne przybierają formę organizacyjną danego typu osoby prawnej (spółdzielni, spółki handlowej mającej osobowość prawną, czy zrzeszenia branżowego), określonej w akcie założycielskim tworzącym daną grupę producentów rolnych. ${ }^{30}$ Powyższa propozycja pozwala na wyodrębnienie wśród ogółu gospodarstw rolnych, przynależnych do własności prywatnej, następujących kategorii: gospodarstw indywidualnych prowadzonych przez rolników - osoby fizyczne, gospodarstw należących do grup producentów rolnych, gospodarstw spółdzielczych - spółdzielni produkcji rolnej oraz gospodarstw państwowych. Wprawdzie, jak wyżej powiedziano, Konstytucja RP zapewnia równą, dla wszystkich kategorii własności, ochronę prawną, jednakże zróżnicowane są reguły funkcjonowania i wykonywania własności państwowej, spółdzielczej oraz własności należącej do osób fizycznych. Określenie statusu prawnego gospodarstwa rolnego ma także istotne znaczenie z punktu widzenia bezpieczeństwa obrotu, aby kontrahenci danego gospodarstwa mieli świadomość zasad funkcjonowania gospodarstwa w obrocie, a zwłaszcza zasad odpowiedzialności za zaciągnięte zobowiązania. 
Keywords: private property, public property, state agricultural holdings, cooperative agricultural holdings, individual agricultural holdings

In the nineties of the last century there was a return to the traditional distinction between private property and public property, which is the division derived from the basic division of private law and public law. At the same time there was retained the subjective diversity between state agricultural holdings, cooperative agricultural holdings and individual agricultural holdings. Each agricultural holding as set of factors of agricultural production, which is organized as economic unit, does not serve to realize the interest, or the public purpose, therefore in the property classification into categories of public and private property, agricultural holding should be ranked as private property, regardless of the legal nature (legal entity or natural person) of the entity who is its owner. Among the total number of agricultural holdings there must be extracted the following categories: individual holdings run by farmers -individual natural persons; holdings belonging to the agricultural producer groups; cooperative holdings, run by agricultural production cooperatives, and state holdings. 